\title{
INOCULATION OF DIAZOTROPHIC BACTERIA AND NITROGEN FERTILIZATION IN TOPDRESSING IN IRRIGATED CORN ${ }^{1}$
}

\author{
VANESSA ZIRONDI LONGHINI ${ }^{2 *}$; WÉSLEY CARLOS ROSSINI DE SOUZA ${ }^{3}$; MARCELO ANDREOTTI ${ }^{3}$; \\ NATALIA DE ÁVILA SOARES ${ }^{4}$; NÍDIA RAQUEL COSTA ${ }^{5}$
}

\begin{abstract}
Corn is a nitrogen-intensive crop, and the use of management practices such as inoculation of the seed with diazotrophic bacteria, which can maximize crop productivity and reduce the need of nitrogen fertilizers, may result in lower production costs. The present study aimed to evaluate the effect of inoculation of corn seed with Azospirillum brasilense and controlled addition of nitrogen to topdressing on the nutrition, production components, and productivity of crop grain. The experimental design was a randomized block design, with four replications in a $2 \times 5$ factorial scheme. The treatments consisted of inoculation or not of corn seed with $A$. brasilense (at $100 \mathrm{~mL}$ per $25 \mathrm{~kg}$ of seed) and five nitrogen $(\mathrm{N})$ levels in topdressing $(0,30,60,90$, and $120 \mathrm{~kg} \mathrm{~N} \mathrm{ha}^{-1}$ from urea [45\% N]) were applied when the corn was in the phenological growth stage V6. Foliar macronutrients, foliar chlorophyll index (FCI), production components, and yield of corn grain were valuated. Inoculation of corn seeds with $A$. brasilense increased plant height and grain yield. Fertilization in topdressing, with $\mathrm{N}$ levels up to $120 \mathrm{~kg} \mathrm{ha}^{-1}$, linearly increased the foliar nutrients and productivity of corn cultivated in the spring/summer in the low-altitude Cerrado region of Brazil.
\end{abstract}

Keywords: Azospirillum brasilense. Zea mays. nitrogen. no-tillage system.

\section{INOCULAÇ̃̃O DE BACTÉRIA DIAZOTRÓFICA E ADUBAÇÃO NITROGENADA DE COBERTURA EM MILHO IRRIGADO}

\begin{abstract}
RESUMO - O milho é uma cultura exigente em nitrogênio e a utilização de práticas de manejo como a inoculação das sementes com bactérias diazotróficas, poderão maximizar a produtividade da cultura, atrelados a redução do uso de adubos nitrogenados, podendo refletir em menor custo de produção. O presente trabalho objetivou avaliar o efeito da inoculação de sementes de milho com Azospirillum brasilense e adição controlada de nitrogênio em cobertura sobre a nutrição, componentes da produção e produtividade de grãos da cultura. $\mathrm{O}$ delineamento experimental foi o de blocos casualizados, com quatro repetições, em esquema fatorial $2 \times 5$. Os tratamentos foram constituídos pela inoculação ou não das sementes do milho com $A$. brasilense (dose de 100 $\mathrm{mL}$ para $25 \mathrm{~kg}$ de sementes) e cinco doses de nitrogênio $(\mathrm{N})$ em cobertura $\left(0,30,60,90\right.$ e $120 \mathrm{~kg} \mathrm{~N}^{-1}$ fonte ureia $[45 \% \mathrm{~N}]$ ) foram aplicadas quando o milho estava no estádio fenológico V6. Teores de macronutrientes foliares, o índice de clorofila foliar (FCI), os componentes da produção e a produtividade de grãos do milho foram avaliados. Constatou-se que a inoculação das sementes de milho com $A$. brasilense incrementou a altura de plantas e a produtividade de grãos. A adubação em cobertura, com a dose de até $120 \mathrm{~kg} \mathrm{~N} \mathrm{ha}^{-1}$, aumentou linearmente os teores nutricionais foliares e a produtividade de grãos do milho irrigado cultivado na primavera/ verão na região de Cerrado de baixa altitude do Brasil.
\end{abstract}

Palavras-chave: Azospirillum brasilense. Zea mays. nitrogênio. sistema plantio direto.

\footnotetext{
*Corresponding author

${ }^{1}$ Received for publication in 03/16/2015; accepted in 03/08/2016.

Work of scientific iniciation FAPESP's first author.

${ }^{2}$ Department of Animal Science, College of Agricultural Sciences and Veterinary Medicine, Universidade Estadual Paulista, Jaboticabal, SP, Brazil; ne_longhini@hotmail.com.

${ }^{3}$ Department of Soil Science, College of Engineering, Universidade Estadual Paulista, Ilha Solteira, SP, Brazil; wesley_rossini@hotmail.com,dreotti@agr.feis.unesp.br.

${ }^{4}$ Department of Animal Science, Universidade Federal dos Vales de Jequetinhonha e Mucuri, Diamantina, MG, Brazil; natalia.avila@hotmail.com.

${ }^{5}$ Department of Crop Science, College of Agricultural Science, Universidade Estadual Paulista, Botucatu, SP, Brazil; nidiarcosta@gmail.com
} 


\section{INTRODUCTION}

Cultivated throughout many areas of Brazil and used in different production systems, corn (Zea mays L.) is a cereal of great importance for agribusiness, human consumption, and animal production (CONAB, 2015). In the growing season 2014/2015, Brazilian corn production was approximately 79.0 million tons in about 15.73 million hectares, resulting in an average yield of $5146 \mathrm{~kg} \mathrm{ha}^{-1}$ (CONAB, 2015).

The corn crop is highly dependent on the use of fertilizers to ensure high yields, which and nitrogen $(\mathrm{N})$ is the most required nutrient (COSTA et al., 2012a). However, in corn production systems, the need for fertilizers is known as one of the factors that increases the production costs (COSTA et al., $2012 b$ ); in addition, its misuse can cause environmental harm. However, it is known that inoculating corn seeds with diazotrophic bacteria can improve the crop nitrogen supply (DARTORA et al., 2013; KAPPES et al., 2013) and can thereby reduce the need for externally applied nitrogen fertilizers.

Low natural availability of nutrients, especially nitrogen, in the soils of tropical regions a feature of the low-altitude Cerrado region of Brazil can result in low crop yields (OLIVEIRA et al., 2009). Thus, it is necessary to adopt appropriate crop management methods, including the use of additional nutrient sources, especially nitrogen in topdressing, to ensure favorable conditions for proper plant development (COSTA et al., 2012a). Increased production and productivity of corn resulting from the addition of nitrogen have been described in several studies (GAVA et al., 2010; MELO et al., 2011; COSTA et al., 2012a). Corn needs ample nitrogen, especially in no-tillage systems (NTS) (COSTA et al., 2012a), because this element is part of the chlorophyll molecule and is key in crucial proteins, enzymes, and nucleic acids, which are essential for growth and high grain yield (GROSS et al., 2006).

In this sense, research is needed to find new techniques that can contribute to improved corn yield in agricultural production-intensive systems, especially in the NTS, especially methods that can reduce crop production costs. One alternative to traditional fertilization methods is inoculation of corn seeds with diazotrophic bacteria, which has been found to decrease the need for nitrogen fertilizer application (LANA et al., 2012; KAPPES et al., 2013; DARTORA et al., 2013).

Boddey and Döbereiner (1995) discovered the potential of microaerobic diazotrophic bacteria, especially those of the genus Azospirillum, to fix atmospheric nitrogen in free living condition. These bacteria are associated with the rhizosphere of corn and may improve nitrogen nutrition (FIGUEIREDO et al., 2009), promote plant growth by the production of hormones (NOVAKOWISKI et al., 2011) such as auxin and gibberellins, or increase the availability of phosphorus to plants (HUNGRIA et al., 2010).

The increase in corn yield due to inoculation with Azospirillum in trials conducted in Brazil is correlated with an increase in the absorption of not only nitrogen but also other nutrients such as phosphorus (P) and potassium (K) (DARTORA et al., 2013; KAPPES et al., 2013). These nutrients are of great importance in tropical soils, where they are naturally scarce. This fact has also been reported in other countries (BASHAN; HOLGUIN, 1997; STEENHOUDT; VANDERLEYDEN, 2000; BASHAN; HOLGUIN; DE-BASHAN, 2004), where improvements were found in root volume and soil exploitation.

The benefits of inoculation of cereal crops with diazotrophic bacteria have been reported in other studies as well (DALLA SANTA et al., 2004; SALA et al., 2008). Hungria et al. (2010) found that the use of $A$. brasilense in corn resulted in a $30 \%$ increase in productivity, corresponding to $823 \mathrm{~kg}$ ha ${ }^{1}$, compared to control without inoculation. However, some studies have found conflicting results. Bartchechen et al. (2010) and Godoy et al. (2011) did not find that inoculation of $A$. brasilense increased grain yield $\left(\mathrm{kg} \mathrm{ha}^{-1}\right)$.

In this sense, the commercial use of bacteria that fix atmospheric nitrogen in grasses is still emerging, with inconsistent results for various crop systems, particularly in tropical conditions of NTS. Therefore, the present study aimed to evaluate the effect of inoculating corn seeds with $A$. brasilense and varying the nitrogen levels in topdressing on the nutrition, production aspects, and productivity of corn in the low-altitude Cerrado region.

\section{MATERIAL AND METHODS}

The study was conducted from November 2011 to August 2013, in an irrigated plot of the Farm of Teaching, Research and Extension (FTRE)-Sector Crops of the University of Ilha Solteira (SP)UNESP, which is located in Selvíria in the State of Mato Grosso do Sul $\left(20^{\circ} 18^{\prime} \mathrm{S}\right.$ and $51^{\circ} 22^{\prime} \mathrm{W}$, elevation $370 \mathrm{~m}$ ). Two sequential experiments were conducted in the spring/summer of two growing seasons (2011/2012 and 2012/2013) in the lowaltitude Cerrado region.

The Köppen climate type is Aw, characterized as humid tropical with a rainy season in summer and a dry season in winter. During the experiment, data were collected monthly by the weather station located in FTRE on maximum, average, and minimum temperature, and rainfall (Figure 1). Climatic data were in accord with historical averages of the region, with average annual rainfall of $1370 \mathrm{~mm}$, average temperature of $23.5^{\circ} \mathrm{C}$, and relative humidity between $70 \%$ and $80 \%$. 


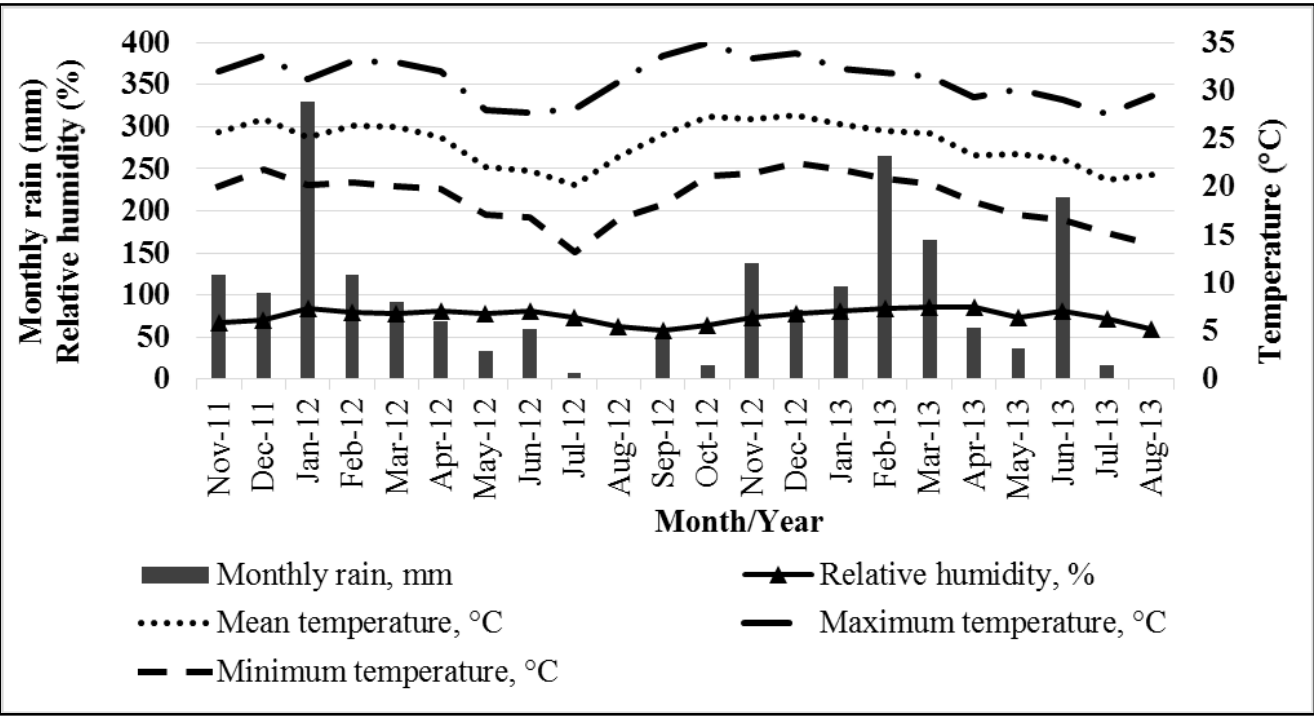

Figure 1. Climate data obtained from the UNESP weather station in Selvíria, Mato Grosso do Sul State, Brazil, from November 2011 to August 2013.

The soil in the study region was classified as a clayey Typic Haplorthox (SANTOS et al., 2006). The experimental area was under an NTS for $9 \mathrm{y}$, and was under cultivation with winter bean before the initiation of the experiment. Soil samples were collected to determine fertility in September 2011 and September 2012 for each of the two respective growing seasons. To determine the soil's chemical properties, we used the methodology proposed by Raij et al. (2001), and collected 20 soil samples with deformed structures using a screw auger to a soil depth in the $0-0.20 \mathrm{~m}$ (Table 1$)$.

Table 1. Soil chemical characteristics in the experimental area before initiation of the experiment $(0-0.20 \mathrm{~m})$.

\begin{tabular}{cccccccccc}
\hline Year & $\mathrm{P}_{(\mathrm{resin})}$ & $\mathrm{SOM}^{*}$ & $\mathrm{pH}$ & $\mathrm{K}_{\mathrm{ex}}$ & $\mathrm{Ca}_{\mathrm{ex}}$ & $\mathrm{Mg}_{\mathrm{ex}}$ & $\mathrm{H}+\mathrm{Al}$ & $\mathrm{CEC}^{\dagger}$ & $\mathrm{BS}^{\dagger \dagger}$ \\
\hline & $\left(\mathrm{mg} \mathrm{dm}^{-3}\right)$ & $\left(\mathrm{g} \mathrm{dm}^{-3}\right)$ & $\left(\mathrm{CaCl}_{2}\right)$ & & $---------\left(\mathrm{mmol}_{\mathrm{c}} \mathrm{dm}^{-3}\right)$ & ----------- & & $(\%)$ \\
\hline 2011 & 68 & 23 & 5.8 & 3 & 34 & 26 & 20 & 82.6 & 76 \\
\hline 2012 & 42 & 22 & 4.9 & 3 & 23 & 19 & 31 & 76.1 & 59 \\
\hline
\end{tabular}

${ }^{\ddagger}$ Soil organic matter.

${ }^{\dagger}$ Cation exchange capacity.

${ }^{\dagger}$ Base saturation.

The area was irrigated by sprinkler (center-pivot) considering limiting water range for the crop in study. Water holding capacity (WHC) was calculated using the following equation:

$\mathrm{WHC}(\mathrm{mm})=[(\mathrm{FC}-\mathrm{PWP}) / 100] \times \mathrm{SD} \times \mathrm{EDRS}$

Where FC is field capacity (\%), PWP is permanent wilting point $(\%), \mathrm{SD}$ is soil density $\left(\mathrm{g} \mathrm{dm}^{-3}\right)$, and EDRS is the effective depth of the root system (m). Data obtained from the soil water retention curve were $\mathrm{FC}=20.25 \%$, $\mathrm{PWP}=14.58 \%$, $\mathrm{SD}=1.310 \mathrm{~g} \mathrm{dm}^{-3}$, and EDRS $=0.20 \mathrm{~m}$. Therefore, the WHC of the soil in this study was $14.86 \mathrm{~mm}$.

Irrigation water was broadcast with a flow rate of $3.3 \mathrm{~mm} \mathrm{~h}^{-1}$. Irrigation was applied any time the maximum evapotranspiration of the crop (ETm) reached $8.25 \mathrm{~mm}$ (less than $44.3 \%$ of the WHC). ETm was estimated using the following equation:
$\operatorname{ETm}\left(m m\right.$ day $\left.^{-1}\right)=\mathrm{Kc} \times \mathrm{ETo}$

Where $\mathrm{Kc}$ is the crop coefficient, and ETo is the reference evapotranspiration. ETo was estimated by the following equation:

$\operatorname{ETo}\left(m m\right.$ day $\left.^{-1}\right)=\mathrm{Kp} \times \mathrm{ECA}$

Where $\mathrm{Kp}$ is the tank coefficient for the Class A tank, and ECA is evaporation from the Class A tank $\left(\mathrm{mm}\right.$ day $\left.^{-1}\right)$. Water evaporation $(\mathrm{mm})$ was measured daily from a Class A tank. Kp was calculated as proposed by Doorenbos and Pruitt (1977) based on the surrounding area, wind speed, and relative humidity.

The experiment was conducted using a randomized complete block design with four replicates, and the treatments were distributed in a 2 $\times 5$ factorial scheme. The treatments consisted of 
inoculation of corn seeds with the diazotrophic bacteria $A$. brasilense and five levels of nitrogen in topdressing $\left(0,30,60,90\right.$, and $\left.120 \mathrm{~kg} \mathrm{~N} \mathrm{ha}^{-1}\right)$, using urea as the nitrogen source $(45 \% \mathrm{~N})$. The portions of the second growing season (2012/2013) were deployed in the same area the first growing season (2011/2012).

In both growing seasons, $15 \mathrm{~d}$ before corn was sown, plants present in the experimental area were dried to facilitate straw preparation for continuity of the NTS. The herbicide glyphosate [isopropylamine salt of $\mathrm{N}$-(phosphonomethyl) glycine] (1.44 g acid-equivalent ha-1) was used at a spray volume of $200 \mathrm{~L}$ ha-1, and the plants were crushed with a plant residue horizontal crusher (Triton).

In both growing seasons, corn seed was inoculated with $A$. brasilense just before crop sowing, the shadow. The source of bacteria was the liquid inoculant AZO Total ${ }^{\circledR}$ (EMBRAPA), used at the dose recommended by the manufacturer of 100 $\mathrm{mL}$ per $25 \mathrm{~kg}$ of seed.

We used the simple hybrid of corn AG 8088 YG in both growing seasons. Mechanical sowing was performed on November 10, 2011, and October 16,2012 , using a no-till drill with a rod type trencher mechanism (machete) for the NTS. The spacing used was $0.90 \mathrm{~m}$, and seed was planted to a depth of approximately $0.04 \mathrm{~m}$, with the aim to reach a final plant population between 55,000 and 60,000 plants $\mathrm{ha}^{-1}$. Each plot consisted of four rows of corn, $6 \mathrm{~m}$ long, totaling $21.60 \mathrm{~m}^{2}$. Fertilization was carried out at the time of sowing; in the 2011/2012 season the application consisted of $400 \mathrm{~kg} \mathrm{ha}^{-1}$ formulated as 04 -30-10 (16 kg ha ${ }^{-1} \mathrm{~N}, 120 \mathrm{~kg} \mathrm{ha}^{-1} \mathrm{P}_{2} \mathrm{O}_{5}$, and 40 $\mathrm{kg} \mathrm{ha}^{-1}$ of $\mathrm{K}_{2} \mathrm{O}$ ), whereas in the 2012/2013 season, the application consisted of $350 \mathrm{~kg} \mathrm{ha}^{-1}$ formulated as $08-28-16\left(28 \mathrm{~kg} \mathrm{ha}^{-1} \mathrm{~N}, 80 \mathrm{~kg} \mathrm{ha}^{-1} \mathrm{P}_{2} \mathrm{O}_{5}\right.$, and 56 $\mathrm{kg} \mathrm{ha}^{-1} \mathrm{~K}_{2} \mathrm{O}$ ), according to the recommendations of Cantarella et al. (1996).

Nitrogen fertilization in topdressing was performed manually, by application of the fertilizer close to the corn rows, on December 9, 2011, for the first growing season $(2011 / 2012)$ and on November 9, 2012, for the second growing season (2012/2013). It was applied at levels of $0,30,60,90$, and $120 \mathrm{~kg}$ $\mathrm{N}^{-1}{ }^{-1}$; urea $(45 \% \mathrm{~N})$ was the nitrogen source. The topdressing was applied when the corn was in the V6 growth stage (six fully developed leaves) (CANTARELLA et al., 1996). Subsequently to this application, the area was irrigated with a blade of approximately $15 \mathrm{~mm}$ to prevent excessive loss of $\mathrm{N}-\mathrm{NH}_{3}$ by volatilization.

When the corn plants reached full flowering stage, on December 30, 2011 and on December 13, 2012 , they were collected in the two central rows $4 \mathrm{~m}$ long, and 20 middle thirds of the opposing leaves immediately below the ears were sampled (MALAVOLTA et al., 1997). The collected leaves were cleaned and dried at $65^{\circ} \mathrm{C}$ in a forced-air circulation oven to constant weight, subsequently ground and submitted for analysis of dry mass and concentrations of $\mathrm{N}, \mathrm{P}, \mathrm{K}, \mathrm{Ca}, \mathrm{Mg}$, and $\mathrm{S}$ according to the methodology suggested by Malavolta et al. (1997). On the same days as the collection of leaf samples for laboratory analysis, readings of the foliar chlorophyll index (FCI) were also performed using a digital chlorophyll meter (CFL 1030 - Falker). Readings were taken from the middle third of leaves inserted in the main ears, of 10 leaves per plot (MALAVOLTA et al., 1997).

The corn was harvested when the plants had reached full physiological maturity stage, on March 21, 2012, and February 28, 2013, for the first and second growing seasons, respectively. Then, the mean baseline diameter of stems (BDS) (stem the second visible internode, counted starting from the soil surface) was determined in 10 plants/plot with the assistance of a digital caliper. Average plant height $(\mathrm{PH})$ and average height of ear insertion (HEI) were determined using a ruler graduated in centimeters. The number of plants per meter, 4-m per row, was counted to calculate plant population per hectare (PP). The same 4-m rows were used to evaluate the number of ears $\mathrm{m}^{-1}$ and to calculate the number of ears per hectare (NE).

Ten ears were collected at random per plot, to determine the ear length (EL), ear diameter (ED), and weight of 100 seeds (M100) (13\% wet basis). To determine the grain yield (GY), all ears were collected in a plot (two central rows, disregarding 1 $\mathrm{m}$ from each end), threshed in a heavy mechanical thresher for conversion into $\mathrm{kg} \mathrm{ha}^{-1}$ (13\% wet basis).

The results were submitted to analysis of variance by $\mathrm{F}$ test, and posterior application of the Tukey test at the $5 \%$ probability level $(\mathrm{P} \leq 0.05)$, to compare the means of the effect of inoculation and regression analysis to $\mathrm{N}$ levels in topdressing. All calculations were performed using the statistical program SISVAR $®$ (FERREIRA, 2011).

\section{RESULTS AND DISCUSSION}

In the inoculation of corn seed and nitrogen fertilization in topdressing for nutrient content, no significant differences were found in the components of production and yield of corn grain between the two analyzed growing seasons (2011/2012 and 2012/2013).

Azospirillum inoculation of corn seed had an effect on the foliar chlorophyll index (FCI) in the growing season 2011/2012, showing higher values than those found in the corn that was not inoculated (Table 2). This result corroborates those described by Bashan, Holguin and De-Bashan (2004) that evaluated Azospirillum bacteria and the plant-Azospirillum interrelationship, and found an increase in various photosynthetic pigments (chlorophyll a and b) and photoprotective pigments (carotenoids and 
xanthophylls) in plants. Barassi et al. (2008) reported improvements in photosynthetic parameters of the leaves, including chlorophyll content and stomatal conductance, with a higher biomass production and increased plant height of corn inoculated with Azospirillum.

Table 2. Foliar chlorophyll index (FCI) and corn leaf concentrations of $\mathrm{N}, \mathrm{P}, \mathrm{K}, \mathrm{Ca}, \mathrm{Mg}$, and S $\left(\mathrm{g} \mathrm{kg}^{-1}\right)$, as a function of inoculation of seeds with Azospirillum brasilense and nitrogen application rates, during growing seasons 2011/2012 and $2012 / 2013$

\begin{tabular}{|c|c|c|c|c|c|c|c|}
\hline & FCI & $\mathbf{N}$ & $\mathbf{P}$ & $\mathbf{K}$ & $\mathbf{C a}$ & Mg & $\mathbf{S}$ \\
\hline & \multicolumn{7}{|c|}{ - } \\
\hline Treatments & \multicolumn{7}{|c|}{ Growing season 2011/2012 } \\
\hline With inoculation & $61.6 \mathrm{a}^{\S * *}$ & $26.8 \mathrm{a}^{*}$ & $3.8 \mathrm{a}^{* *}$ & $21.7 \mathrm{a}^{* *}$ & $2.6 \mathrm{~b}^{* *}$ & $1.7 \mathrm{a}$ & $2.6 \mathrm{a}^{*}$ \\
\hline Without inoculation & $55.1 \mathrm{~b}$ & $25.0 \mathrm{~b}$ & $3.3 \mathrm{~b}$ & $20.8 \mathrm{~b}$ & $3.0 \mathrm{a}$ & $1.8 \mathrm{a}$ & $2.4 \mathrm{~b}$ \\
\hline \multicolumn{8}{|l|}{ Nitrogen rates $\left(\mathrm{kg} \mathrm{ha}^{-1}\right)$} \\
\hline 0 & 55.9 & 26.1 & 3.6 & $20.9^{* *(1)}$ & 2.9 & 1.8 & 2.4 \\
\hline 30 & 57.0 & 25.5 & 3.4 & 20.4 & 2.9 & 1.8 & 2.5 \\
\hline 60 & 60.0 & 26.0 & 3.7 & 20.6 & 3.0 & 1.9 & 2.6 \\
\hline 90 & 57.6 & 25.6 & 3.3 & 22.0 & 2.6 & 1.7 & 2.5 \\
\hline 120 & 61.2 & 26.3 & 3.7 & 22.3 & 2.7 & 1.7 & 2.6 \\
\hline VC (\%) & 10.3 & 8.7 & 14.0 & 4.5 & 11.5 & 16.6 & 9.5 \\
\hline Treatments & \multicolumn{7}{|c|}{ Growing season 2012/2013 } \\
\hline With inoculation & $49.5 \mathrm{a}$ & $23.7 \mathrm{a}$ & $2.8 \mathrm{a}$ & $21.3 \mathrm{a}^{* *}$ & $3.1 \mathrm{~b}^{* *}$ & $2.0 \mathrm{~b}^{* *}$ & $1.5 \mathrm{a}$ \\
\hline Without inoculation & $48.8 \mathrm{a}$ & $22.4 \mathrm{a}$ & $2.9 \mathrm{a}$ & $15.0 \mathrm{~b}$ & $3.5 \mathrm{a}$ & $2.2 \mathrm{a}$ & $1.6 \mathrm{a}$ \\
\hline \multicolumn{8}{|l|}{ Nitrogen rates $\left(\mathrm{kg} \mathrm{ha}^{-1}\right)$} \\
\hline 0 & $32.9^{* *(2)}$ & $16.0^{* *(3)}$ & $2.7^{* *(4)}$ & 17.5 & $2.8^{* *(5)}$ & $1.7^{* *(6)}$ & $1.2^{* *(7)}$ \\
\hline 30 & 43.7 & 20.3 & 2.6 & 17.9 & 3.2 & 1.9 & 1.4 \\
\hline 60 & 51.8 & 23.8 & 2.7 & 18.2 & 3.4 & 2.1 & 1.5 \\
\hline 90 & 57.3 & 26.6 & 2.9 & 18.5 & 3.5 & 2.2 & 1.7 \\
\hline 120 & 60.1 & 28.5 & 3.3 & 18.8 & 3.5 & 2.4 & 1.8 \\
\hline VC (\%) & 10.6 & 12.2 & 10.0 & 8.3 & 8.0 & 10.1 & 8.4 \\
\hline
\end{tabular}

$\S$ Values followed by the same letter are not significantly different at $\mathrm{p} \leq 0.05$ according to Tukey test. $* \mathrm{p}<0.05, * * \mathrm{p}<$ 0.01 .

$\dagger \mathrm{VC}=$ Variation coefficient.

${ }^{(1)} \mathrm{K}=20.4+0.014 \mathrm{~N}\left(\mathrm{r}^{2}=0.624^{* *}\right)$.

(2) $\mathrm{FCI}=28.8+3.79 \mathrm{~N}\left(\mathrm{r}^{2}=0.938^{* *}\right)$.

(3) $\mathrm{N}=23.65+0.313 \mathrm{~N}\left(\mathrm{r}^{2}=0.974^{* *}\right)$.

${ }^{(4)} \mathrm{P}=2.36+0.016 \mathrm{~N}\left(\mathrm{r}^{2}=0.732^{* *}\right)$.

(5) $\mathrm{Ca}=2.81+0.0160 \mathrm{~N}\left(\mathrm{r}^{2}=0.774^{* *}\right)$.

${ }^{(6)} \mathrm{Mg}=1.60+0.0155 \mathrm{~N}\left(\mathrm{r}^{2}=0.954^{* *}\right)$.

(7) $\mathrm{S}=1.11+0.0144 \mathrm{~N}\left(\mathrm{r}^{2}=0.990^{* *}\right)$.

Leaf macronutrients in the growing season 2011/2012 (Table 2) showed higher concentrations of $\mathrm{N}, \mathrm{P}, \mathrm{K}, \mathrm{S}$, and reduced levels of $\mathrm{Ca}$ in the inoculated corn compared to the without inoculation. This effect on the Ca can be attributed to competitive inhibition by increased absorption of $\mathrm{K}$ (MALAVOLTA et al., 1997; BASHAN; HOLGUIN; DE-BASHAN, 2004). The increased nutritional content in corn leaves $(\mathrm{N}, \mathrm{P}, \mathrm{K}, \mathrm{S})$ is due to the main action of diazotrophic bacteria of the genus Azospirillum that are associated with the rhizosphere of plants. Beyond promoting fixation of atmospheric $\mathrm{N}$, these bacteria can enhance the production of auxins, substances responsible for the stimulation of growth (especially root) and improvement exploitation of the soil, and consequently improved nutrient absorption and plant 
nutrition (BASHAN; HOLGUIN, 1997; STEENHOUDT; VANDERLEYDEN, 2000).

Analysis of nitrogen levels in topdressing showed positive linear regression fitting to $\mathrm{K}$ content in the 2011/2012 growing season (Table 2), demonstrating a need for increased nutrient absorption to maintain a $\mathrm{N}: \mathrm{K}$ balance near $1: 1.2$. Casagrande and Fornasieri Filho (2002) found an increase in the content of leaf macronutrients of corn in response to increased nitrogen levels $(0,30,60$, and $90 \mathrm{~kg} \mathrm{ha}^{-1}$ of $\mathrm{N}$, using urea).

Leaf nitrogen content in the growing season $2011 / 2012$ was slightly below the critical level (27$35 \mathrm{~g} \mathrm{~kg}^{-1}$ ) described in corn by Cantarella et al. (1996), and was not affected by the nitrogen level in the topdressing. This may be a result of the area's cropping history and to the 9 y of NTS that characterized the experimental area during the study. According to Anghinoni (2007), in the first $5 \mathrm{y}$ under NTS, nitrogen demand is high as a function of the immobilization of this nutrient in the crop straw, and 5-10 y after adoption of the NTS, some mineralization of $\mathrm{N}$ may already exist in relation to the immobilization of this nutrient in plant residue constituents of straw. Therefore, it may be that the system has not adequately provided this nutrient for the development of corn as the low fertility of Cerrado soils, and the quick decomposition and mineralization of plant residues in tropical regions, which also has low accumulation of organic matter.

Low levels of $\mathrm{N}$ applied in topdressing to corn may also be a factor. According Cantarella et al. (1996), for a GY of 8-10 $\mathrm{t} \mathrm{ha}^{-1}$, the recommendation is $50-120 \mathrm{~kg} \mathrm{ha}^{-1} \mathrm{~N}$ in topdressing, depending on the expected response class. In some current production systems, with the adoption of more modern hybrids, irrigation, and NTS, the recommended nitrogen level in topdressing is much higher. In a study conducted by Costa et al. (2012a) nitrogen fertilization in topdressing was evaluated in corn intercropped with tropical forages of the same region and under very similar conditions to those seen in this study; $200 \mathrm{~kg} \mathrm{~N}^{-1}$ resulted in the highest crop production level.

In the first growing season (2011/2012), the corn was grown in succession to a winter bean crop, and nitrogen fertilization had no effect (Table 2). However, in the second growing season (2012/2013), it was necessary to add 90-120 kg ha ${ }^{-1}$ in the topdressing to meet the demand of the crop. This shows that even in consolidated NTS (ANGHINONI, 2007), the demand for nitrogen fertilizer depends on the cultivation system, history of the area, and crop rotation. The contents of other leaf nutrients $(\mathrm{P}, \mathrm{K}, \mathrm{Ca}, \mathrm{Mg}$, and $\mathrm{S})$, were within ranges considered appropriate by Cantarella et al. (1996), regardless of treatment evaluated (Table 2, growing season 2011/2012).

In analyzing the two growing season (Table 2 ), it was found that the first growing season
$(2011 / 2012)$, when the corn was grown in succession to winter beans and due to better soil fertility of the experimental area (Table 1), the nutritional content, and FCI index were higher, and there was less effect of $\mathrm{N}$ in topdressing than in the second growing season. However, with the spring/summer corn crop in the growing season 2011/2012 and autumn in 2012, a reduction in soil fertility to the growing season 2012/2013 (Table 1) resulted from the sequence of grasses in the area and a high extraction of nutrients due to crop harvesting. In this growing season (2012/2013), there was a greater effect of $\mathrm{N}$ in topdressing, with linear adjustments for almost all leaf nutrient content and FCI index.

Costa et al. (2012a) evaluated nitrogen fertilization in corn intercropped with two species of Urochloa in NTS, under growing conditions similar to the results obtained in this study. They found that nitrogen fertilization in topdressing in corn crop, up to $200 \mathrm{~kg} \mathrm{ha}^{-1}$ of $\mathrm{N}$, linearly increased the FCI index; the contents of $\mathrm{N}, \mathrm{P}$, and $\mathrm{S}$; as well as the components of production and yield of corn grain; these findings were also similar to the results of the present study. Furthermore, Gava et al. (2010) evaluated the effect of different levels of nitrogen in topdressing of corn $\left(0,50,100,150\right.$, and $200 \mathrm{~kg} \mathrm{ha}^{-1}$ $\mathrm{N}$ ) and obtained increased yield and $\mathrm{N}$ accumulation in the plants.

It was also found that, in the second growing season (2012/2013), inoculation of seeds with Azospirillum spp. resulted in increased $\mathrm{K}$ content (Table 2). Competitive inhibition may have been the cause of this result; that is, with the increase of $\mathrm{K}$, a concomitant reduction of $\mathrm{Ca}$ and $\mathrm{Mg}$ may have occurred.

It is worth noting the effect of inoculation with Azospirillum spp., which according to the literature on studies conducted in Brazil, can be correlated with increased absorption of not only nitrogen, but also other nutrients, a result also reported in other countries (BASHAN; HOLGUIN, 1997; STEENHOUDT; VANDERLEYDEN, 2000; BASHAN; HOLGUIN; DE-BASHAN, 2004), and consistent with the results of the present study.

On the basis of research on inoculation in the field, Okon and Vanderleyden (1997) concluded that $A$. brasilense promotes increased in the yield of important crops (corn, wheat, and rice) under various conditions of climate and soil, and they further point out that the improvements from inoculation not only assist in the biological fixation of $\mathrm{N}_{2}$, but also promote increased absorption surfaces of plant roots and, consequently, increased volume of soil substrate explored, can thus to increase the absorption of other nutrients. According these authors, inoculation of seed with $A$. brasilense can modify the morphology of the plant's root system, increasing the number of rootlets and the diameter of lateral and adventitious roots. The benefits to plants of $A$. brasilense inoculation can be attributed to the production of 
growth-promoting substances produced by such bacteria, including auxins, cytokinins and giberillins (BASHAN; HOLGUIN; DE-BASHAN, 2004), which increase nutrient absorption, as verified in this study.

There were adjustments of positive linear regressions to the concentrations of $\mathrm{N}, \mathrm{P}, \mathrm{Ca}, \mathrm{Mg}$, and $\mathrm{S}$ for the growing season 2012/2013 (Table 2), due to $\mathrm{N}$ levels in the topdressing. However, concentrations of leaf nitrogen resulting from inoculation were below the critical level of 27-35 g $\mathrm{kg}^{-1}$ (CANTARELLA et al., 1996) up to a nitrogen level of $60 \mathrm{~kg} \mathrm{ha}^{-1}$. The values of other nutrients were within the appropriate range regardless of the treatments. Concentrations of $\mathrm{S}$ were below critical levels (1.5-3.0 $\left.\mathrm{g} \mathrm{kg}^{-1}\right)$, with exception of the nitrogen levels of 60,90 , and $120 \mathrm{~kg} \mathrm{ha}^{-1} \mathrm{~N}$ delivered in topdressing (Table 2, growing season 2012/2013). These results indicate the importance of $\mathrm{N}$ in nutrition of corn crop.

Although there was no significant difference in FCI due to inoculation of corn seed (Table 2, growing season 2012/2013), there was positive linear adjustment with the increment of $\mathrm{N}$ level in the topdressing, since this nutrient is a constituent of the chlorophyll molecule.

Regarding the growth of corn crop (Table 3), in the growing seasons 2011/2012, it appears that inoculation of corn seed with $A$. brasilense increased $\mathrm{PH}$ and HEI, whereas in the growing seasons 2012/2013, it increased only PH. These results corroborate those obtained by Cavallet et al. (2000) that describe the effect of $A$. brasilense bacteria on the growth of grasses, attributing this fact to the physiological mechanisms, genotype of the seed used, increase growth of lateral and adventitious roots, increased activity of photosynthetic enzymes, and increased nitrogen assimilation, which may have increased the yield of both dry matter and grain. Inoculation and nitrogen fertilization had no effect on the BDS, PP, EL, and ED during either of the two growing seasons (Table 3). This result can be attributed to the history of the cultivated area, which was under a NTS and had good soil fertility during the experiment, especially in the growing season 2011/2012 (Table 1).

In the first growing season (2011/2012), although the inoculation of corn seeds with $A$. brasilense significantly reduced the NE, there was a concomitant increase of weight, here represented by W100, which resulted in a significant increase in GY, compared to the non-inoculated seed controls (Table 3). This result is also reflected in the increase in ED, because larger, heavier grains directly increase the yield. During the next growing season (2012/2013), inoculation had no effect on most variables, with one exception; GY was significantly affected, thus demonstrating the effectiveness of the bacteria in increased yield of the corn crop, which can best be explained by the plant nutrition (Table 2, growing season 2012/2013). The results obtained in this study are similar to those reported by Cavallet et al. (2000), which concluded that inoculation of corn seed with Azospirillum spp. resulted in a significant increase in yield of corn grain.

In terms of the effect of nitrogen fertilization in topdressing, a positive linear adjustment for GY existed in the 2011/2012 growing season. In contrast, in the 2012/2013 season, there was a quadratic adjustment with an estimated maximum point of 97.7 $\mathrm{kg} \mathrm{ha}^{-1} \mathrm{~N}$ on HEI, and positive linear adjustments for $\mathrm{PH}, \mathrm{NE}, \mathrm{EL}, \mathrm{ED}$, and W100, and concomitantly in GY (Table 3).

Thus, nitrogen fertilization and inoculation of corn seed are clearly important for proper plant nutrition to facilitate growth and yield of irrigated corn in the Cerrado, mainly by consecutive cultivation of grasses in succession (corn in growing season 2011/2012 and corn intercropped with Urochloa in the off-season of 2012). It should be noted, however, that even in the control (without nitrogen fertilization in topdressing), good soil fertility combined with cultivation in irrigated NTS, resulted in GY values that were generally greater than $7600 \mathrm{~kg} \mathrm{ha}^{-1}$ (Table 3, growing season 2011/2012), considered high for the region (CONAB, 2015). However, in the second growing season $(2012 / 2013)$, the control had a GY of only $3289 \mathrm{~kg} \mathrm{ha}^{-1}$, reflecting the importance of proper management of nitrogen fertilizer for corn crop. Important practices to be adopted in the current production systems include more technified methods generally, nitrogen fertilization in topdressing, the possibility of inoculation with nitrogen-fixing bacteria, crop rotation, irrigation, cultivation in NTS, and especially the inclusion of legumes in the production system, as was done for the growing season 2011/2012. During this season, the crop that preceded the corn was winter beans, which may have benefited the crop that was planted there next.

The positive results obtained in this study, especially in the first growing season (2011/2012), demonstrate the effectiveness of the practices used in this research. An adequate supply of nitrogen through fertilization in topdressing and inoculation of corn seed with Azospirillum, combined with other practices such as good soil management and conservation, and a NTS with maintenance of soil fertility to adequate levels and irrigation, reflected in good nutrition and development of corn in the Cerrado region. 
Table 3. Corn agronomic characteristics (mean baseline diameter of stems [BDS], plant height [PH], height of ear insertion [HEI], ear length [EL], ear diameter [ED], plant population [PP], number of ears per hectare [NE], weight of 100 seeds [W100], and grain yield [GY]), as a function of the inoculation of seeds with $A$. brasilense and nitrogen application rates. Growing seasons 2011/2012 and 2012/2013.

\begin{tabular}{|c|c|c|c|c|c|c|c|c|c|}
\hline & BDS & PH & HEI & EL & ED & $\mathbf{P P}$ & NE & W100 & GY \\
\hline & $(\mathrm{mm})$ & \multicolumn{2}{|c|}{ (m) } & $(\mathrm{cm})$ & $(\mathrm{mm})$ & \multicolumn{2}{|c|}{$----\left(n^{o} h^{-1}\right)-----$} & (g) & $\left(\mathrm{kg} \mathrm{ha}^{-1}\right)$ \\
\hline & \multicolumn{9}{|c|}{ Growing season 2011/2012 } \\
\hline \multicolumn{10}{|l|}{ Treatments } \\
\hline With inoculation & $23.9 \mathrm{a}^{\S}$ & $2.39 \mathrm{a}^{* *}$ & $1.27 \mathrm{a}^{* *}$ & $18.8 \mathrm{a}$ & $50.3 \mathrm{a}$ & $48426 \mathrm{a}$ & $49676 b^{*}$ & $31.5 \mathrm{a}^{*}$ & $8768 a^{*}$ \\
\hline Without inoculation & $23.1 \mathrm{a}$ & $2.24 \mathrm{~b}$ & $1.16 \mathrm{~b}$ & $18.5 \mathrm{a}$ & $54.3 \mathrm{a}$ & $50278 \mathrm{a}$ & $52315 \mathrm{a}$ & $30.0 \mathrm{~b}$ & $8267 \mathrm{~b}$ \\
\hline \multicolumn{10}{|l|}{ Nitrogen rates $\left(\mathrm{kg} \mathrm{ha}^{-1}\right)$} \\
\hline 0 & 22.6 & 2.32 & 1.25 & 18.6 & 49.7 & 48495 & 50000 & 30.1 & $7628^{* *(1)}$ \\
\hline 30 & 23.0 & 2.25 & 1.15 & 18.4 & 49.5 & 51273 & 52315 & 30.2 & 7993 \\
\hline 60 & 24.2 & 2.30 & 1.22 & 18.9 & 50.5 & 49190 & 49190 & 31.7 & 7924 \\
\hline 90 & 23.0 & 2.35 & 1.22 & 18.6 & 49.9 & 49074 & 51968 & 30.9 & 8877 \\
\hline 120 & 24.5 & 2.35 & 1.23 & 18.8 & 62.1 & 48727 & 51505 & 31.0 & 8912 \\
\hline \multirow[t]{2}{*}{ VC (\%) } & 10.4 & 3.8 & 6.5 & 3.8 & 27.7 & 6.8 & 6.3 & 6.8 & 8.2 \\
\hline & \multicolumn{9}{|c|}{ Growing season 2012/2013 } \\
\hline \multicolumn{10}{|l|}{ Treatments } \\
\hline With inoculation & $22.5 \mathrm{a}$ & $2.25 \mathrm{a}^{* *}$ & $1.17 \mathrm{a}$ & $17.3 \mathrm{a}$ & $48.4 \mathrm{a}$ & $60889 a$ & $54167 \mathrm{a}$ & $29.5 \mathrm{a}$ & $7252 a^{*}$ \\
\hline Without inoculation & $21.9 \mathrm{a}$ & $2.13 \mathrm{~b}$ & $1.12 \mathrm{a}$ & $17.1 \mathrm{a}$ & $48.0 \mathrm{a}$ & $57000 \mathrm{a}$ & $51278 \mathrm{a}$ & $29.4 \mathrm{a}$ & $6297 \mathrm{~b}$ \\
\hline \multicolumn{10}{|l|}{ Nitrogen rates $\left(\mathrm{kg} \mathrm{ha}^{-1}\right)$} \\
\hline 0 & 21.0 & $2.00 * *(2)$ & $0.97 * *(3)$ & $15.8 * *(4)$ & $46.0 * *(5)$ & 59028 & $40833 * *(6)$ & $27.7 *(7)$ & $3289 * *(8)$ \\
\hline 30 & 22.3 & 2.18 & 1.12 & 16.9 & 47.8 & 59722 & 53194 & 28.6 & 6078 \\
\hline 60 & 22.2 & 2.21 & 1.17 & 17.3 & 48.4 & 57639 & 54444 & 29.1 & 7237 \\
\hline 90 & 22.6 & 2.26 & 1.23 & 17.9 & 49.4 & 58750 & 57361 & 30.0 & 8004 \\
\hline 120 & 22.9 & 2.30 & 1.22 & 18.2 & 49.5 & 59583 & 57778 & 31.9 & 9266 \\
\hline VC (\%) & 6.7 & 4.7 & 7.1 & 5.9 & 3.7 & 10.8 & 13.1 & 9.2 & 20.8 \\
\hline
\end{tabular}

$\S$ Values followed by the same letter are not significantly different at $\mathrm{p} \leq 0.05$ according to Tukey test. $* \mathrm{p}<0.05,{ }^{* *} \mathrm{p}<$ 0.01 .

${ }^{\dagger} \mathrm{VC}=$ Variation coefficient.

(1) $\mathrm{GY}=7577+11.51 \mathrm{~N}\left(\mathrm{r}^{2}=0.858^{* *}\right)$.

(2) $\mathrm{PH}=2.05+0.0023 \mathrm{~N}\left(\mathrm{r}^{2}=0.852^{* *}\right)$.

${ }^{(3)} \mathrm{HEI}=0.97+0.0053 \mathrm{~N}-0.000027 \mathrm{~N}^{2}\left(\mathrm{r}^{2}=0.985^{* *} ;\right.$ maximum productivity point $\left.=97.7 \mathrm{~kg} \mathrm{~N} \mathrm{ha}^{-1}\right)$.

(4) $\mathrm{EL}=16.1+0.0188 \mathrm{~N}\left(\mathrm{r}^{2}=0.943^{* *}\right)$.

${ }^{(5)} \mathrm{ED}=46.5+0.0287 \mathrm{~N}\left(\mathrm{r}^{2}=0.899^{* * *}\right)$.

(6) $\mathrm{NE}=45111+126.9 \mathrm{~N}\left(\mathrm{r}^{2}=0.756^{* *}\right)$

(7) $\mathrm{W} 100=27.5+0.0330 \mathrm{~N}\left(\mathrm{r}^{2}=0.936^{* *}\right)$.

${ }^{(8)} \mathrm{GY}=3999+46.27 \mathrm{~N}\left(\mathrm{r}^{2}=0.937^{* *}\right)$. 


\section{CONCLUSIONS}

Inoculation of corn seed with A. brasilense in spring/summer crops increased plant height and grain yield.

Fertilization with topdressing containing nitrogen up to $120 \mathrm{~kg} \mathrm{ha}^{-1}$ linearly increased foliar nutrient levels and irrigated corn grain yield grown in the spring/summer in the Cerrado. The lowest foliar nutrient levels and corn yields were obtained in the first growing year, because the corn crop had been sown in succession to winter beans.

\section{ACKNOWLEDGEMENTS}

To the Foundation for Research Support of the State of São Paulo - FAPESP (Process FAPESP $n \circ 2012 / 19114-3$ ) for granting scientific initiation scholarship to the first author.

\section{REFERENCES}

ANGHINONI, I. Fertilidade do solo e seu manejo em sistema plantio direto. In: NOVAIS, R. F. et al. (Eds.). Fertilidade do solo. Viçosa: Sociedade Brasileira de Ciência do Solo, 2007. v. 1, cap. 15, p. 873-928.

BARASSI, C. A. et al. Potencialidad de Azospirillum en optimizer el crecimiento vegetal bajo condiciones adversas. In: CASSÁN, F. D.; GARCIA DE SALAMONE, I. (Eds.) Azospirillum sp.: cell physiology, plant interactions and agronomic research in Argentina. Argentina: Asociación Argentina de Microbiologia, 2008. p. 4959.

BARTCHECHEN, A. et al. Efeito da inoculação de Azospirillum brasilense na produtividade da cultura do milho (Zea mays $l$ ). Campo Digital, Campo Mourão, v. 5, n. 1, p. 56-59, 2010.

BASHAN, Y.; HOLGUIN, G. Azospirillum - plant relationships: environmental and physiological advances (1990-1996). Canadian Journal of Microbiology, Birmingham, v. 43, n. 2, p. 103-121, 1997.

BASHAN, Y.; HOLGUIN, G.; DE-BASHAN, L. E. Azospirillum-plant relationship physiological, molecular, agricultural, and environmental advances (1997-2003). Canadian Journal of Microbiology, Birmingham, v. 50, n. 8, p. 521-577, 2004.

BODDEY, R. M.; DÖBEREINER, J. Nitrogen fixation associated with grasses and cereals: Recent progress and perspectives for the future. Fertilizer
Research, Dordrecht, v. 42, n. 1, p. 241-250, 1995.

CANTARELLA, H.; RAIJ, B. V; CAMARGO, C. E. O. Cereais. In: RAIJ, B. V. et al., (Eds.). Recomendações de adubação e calagem para o estado de São Paulo. Campinas: Instituto Agronômico \& Fundação, 1997. v. , cap. ,p.43-71.

CASAGRANDE, J. R. R.; FORNASIERI FILHO, D. Adubação nitrogenada na cultura do milho safrinha. Pesquisa Agropecuária Brasileira, Brasília, v. 37, n. 1, p. 33-40, 2002.

CAVALLET, L. E. et al. Produtividade do milho em resposta à aplicação de nitrogênio e inoculação das sementes com Azospirillum spp. Revista Brasileira de Engenharia Agrícola e Ambiental, Campina Grande, v. 4, n. 1, p. 129-132, 2000.

\section{COMPANHIA}

NACIONAL

DE

ABASTECIMENTO (CONAB). Acompanhamento da safra brasileira de grãos, v. 2 - Safra 2014/15, n. 4 - Quarto Levantamento, jan. 2015. 1 Disponível em: <http://www.conab.gov.br>. Acesso em: $14 \mathrm{dez}$. 2015 .

COSTA, N. R. et al. Adubação nitrogenada no consórcio de milho com duas espécies de braquiária em sistema plantio direto. Pesquisa Agropecuária Brasileira, Brasília, v. 47, n. 8, p. 1038-1047, 2012a.

COSTA, N. R. et al. Análises técnicas e econômicas no sistema de integração lavoura-pecuária submetido à adubação nitrogenada. Revista Ceres, Viçosa, v. 59, n. 5, p. 597-605, 2012 b.

DALlA SANTA, O. R. et al. Azospirillum sp. inoculation in wheat, barley and oats seeds greenhouse experiments. Brazilian Archives of Biology and Technology, Curitiba, v. 47, n. 6, p. 843-850, 2004.

DARTORA, J. et al. Adubação nitrogenada associada à inoculação com Azospirillum brasilense e Herbaspirillum seropedicae na cultura do milho. Revista Brasileira de Engenharia Agrícola Ambiental, Campina Grande, v. 17, n. 10, p. 1023 1029, 2013.

DOORENBOS, J.; PRUITT, W. O. Guidelines for predicting crop water requirements. Rome, FAO, 1977. 179 p. (FAO: Irrigation and Drainage Paper, 24)

FERREIRA, D. F. Sisvar: A computer statistical analysis system. Ciência e Agrotecnologia, Lavras, v. 35, n. 6, p. 1039-1042, 2011.

FIGUEIREDO, M. V. B. et al. Potential impact of 
biological nitrogen fixation and organic fertilization on corn growth and yield in low external input systems. In: DANFORTH, A.T. (Ed.). Corn crop production growth, fertilization and yield. New York: Nova Science Publisher, 2009. v. 1 , cap. 5, p. 239-267.

GAVA, G. J. DE C. et al. Produção de fitomassa e acúmulo de nitrogênio em milho cultivado com diferentes doses de ${ }^{15} \mathrm{~N}$-uréia. Semina: Ciências Agrárias, Londrina, v. 31, n. 4, p. 851- 862, 2010.

GODOY, J. C. S. et al. Produtividade de milho em resposta a doses de nitrogênio com e sem inoculação das sementes com Azospirillum brasilense. Campo Digital, Campo Mourão, v. 6, n. 1, p. 26-30, 2011.

GROSS, M. R.; VON PINHO, R. G.; BRITO, A. H. Adubação nitrogenada, densidade de semeadura e espaçamento entre fileiras na cultura do milho em sistema plantio direto. Ciência e Agrotecnologia, Lavras, v. 30, n. 3, p. 387-393, 2006.

HUNGRIA, M. et al. Inoculation with selected strains of Azospirillum brasilense and A. lipoferum improves yields of maize and wheat in Brazil. Plant and Soil, Amsterdam, v. 331, n. 1/2, p. 413-425, 2010.

KAPPES, C. et al. Inoculação de sementes com bactéria diazotrófica e aplicação de nitrogênio em cobertura e foliar em milho. Semina: Ciências Agrárias, v. 34, n. 2, p. 527-538, 2013.

LANA, M. C. et al. Inoculation with Azospirillum, associated with nitrogen fertilization in maize. Revista Ceres, Viçosa, v. 59, n. 3, p. 399-405, 2012.

MALAVOLTA, E.; VITTI, G. C.; OLIVEIRA, S. A. Avaliação do estado nutricional das plantas: princípios e aplicações. 2. ed. Piracicaba, SP: Associação Brasileira para Pesquisa da Potassa e do Fosfato, 1997. 319 p.

MELO, F. B.; CORÁ, J. R.; MILTON, J. Fertilização nitrogenada, densidade de plantas e rendimento de milho cultivado no sistema plantio direto. Revista Ciência Agronômica, Fortaleza, v. 42, n. 1, p. 27-31, 2011.

NOVAKOWISKI, J. H. et al. Efeito residual da adubação nitrogenada e inoculação de Azospirillum brasilense na cultura do milho. Semina: Ciências Agrárias, Londrina, v. 32, n. 4, p. 1687-1698, 2011.

OKON, Y.; VANDERLEYDEN, J. Root-associated Azospirillum species can stimulate plants. Applied and Environmental Microbiology, New York, v. 63, n. 7, p. 366-370, 1997.
OLIVEIRA, F. A. et al. Crescimento do milho adubado com nitrogênio e fósforo em um Latossolo Amarelo. Revista Brasileira de Ciências Agrárias, Recife, v. 4, n. 3, p. 238-244, 2009.

RAIJ, B. V. et al. Análise química para avaliação da fertilidade de solos tropicais. Campinas, SP: Instituto Agronômico, 2001. 285 p.

SALA, V. M. R. et al. Novas bactérias diazotróficas endofíticas na cultura do trigo em interação com a adubação nitrogenada, no campo. Revista Brasileira de Ciências do Solo, Viçosa, v. 32, n. 3, p. 10991106, 2008.

SANTOS, H.G. et al. Sistema brasileiro de classificação dos solos. 2. ed. Rio de Janeiro: Embrapa Solos, 2006. 306 p.

STEENHOUDT, O.; VANDERLEYDEN, J. Azospirillum, a free-living nitrogen-fixing bacterium closely associated with grasses: genetic, biochemical and ecological aspects. FEMS Microbiology Reviews, Amsterdam, v. 24, n. 4, p. 487-506, 2000 